\title{
FAKTOR YANG MEMPENGARUHI PERKEMBANGAN PERUMAHAN SWASTA DU KOTA PADANG
}

\author{
Agisti Amelia Putri, Deva Fosterharoldas, Sani Roychansyah \\ Magister Perencanaan Wilayah dan Kota \\ Departemen Teknik Arsitektur dan Perencanaan, Universitas Gadjah Mada \\ Jalan Grafika No.2 Kampus UGM, Yogyakarta 55281 - Telp +62 (274) 580095 \\ e-mail: agisti.amelia.p@mail.ugm.ac.id
}

\begin{abstract}
ABSTRAK
Kota Padang merupakan salah satu Kota Pantai yang terletak di pesisir Barat Pulau Sumatera. Awal mula perkembangan perumahan swasta adalah di wilayah bagian Barat yang merupakan Kawasan Pelabuhan Muara Batang Arau. Dari waktu ke waktu perkembangan perumahan swasta di Kota Padang terus mengalami pergeseran semakin bergerak menuju wilayah bagian Timur yang merupakan kawasan pinggiran kota yang jauh dari pesisir pantai. Fenomena ini berdampak pada kegiatan alih fungsi lahan secara besar-besaran yang mengakibatkan perubahan struktur ruang Kota Padang dan semakin menghilangkan ciri Kota Padang sebagai Kota Pantai. Hal ini menjadi menarik untuk diteliti sehingga muncul pertanyaan penelitian seperti apa perkembangan perumahan swasta di Kota Padang dan apa saja faktor-faktor yang mempengaruhi perkembangan tersebut. Adapun tujuan penelitian ini adalah menggambarkan perkembangan perumahan swasta di Kota Padang serta mengidentifikasi faktor-faktor yang mempengaruhi perkembangan perumahan swasta di Kota Padang. Pendekatan penelitian yang digunakan adalah deduktif kualitatif rasionalitstik, dimana dalam tahapan analisis menggunakan Sistem Informasi Geografis (GIS) untuk menggambarkan perkembangan perumahan swasta di Kota Padang pada tahun 2007-2016. Hasil penelitian menunjukkan bahwa terjadi perubahan orientasi perkembangan perumahan swasta dari tahun 2007-2016 dari wilayah bagian Barat yaitu Kelurahan Padang Sarai, Kelurahan Lubuk Buaya, Kelurahan Pasie Nan Tigo, Kelurahan Bungo Padang dan Kelurahan Parupuk Tabing mengarah ke wilayah bagian Timur yaitu Kelurahan Balai Gadang, Kelurahan Lubuk Minturun, Kelurahan Gunung Sarik dan Kelurahan Kuranji dengan penambahan luas perumahan swasta sebesar 156 Ha. Faktor-faktor yang mempengaruhi perkembangan perumahan di Kota Padang adalah adalah faktor kebijakan, faktor penduduk, faktor keterbatasan lahan, dan faktor kemitraan.
\end{abstract}

Kata Kunci : Kota Padang, Perkembangan Perumahan Swasta, Faktor-Faktor

\section{ABSTRACT}

Padang City is one of the coastal city located in coastal area of Sumatera Island. The beginning of the development of housing was in the western region which was the Muara Batang Arau Port Area. The development of private housing in the city of Padang continues to shift increasingly moving towards the eastern region which is a suburb far from the coast. This phenomenon affects the activities of large land conversion that resulted in changes in the structure of the Padang City space and increasingly eliminate the characteristics of the City of Padang as a Beach City. This is interesting to study so research questions arise as to the development of private housing in the city of Padang and what are the factors that influence this development. The purpose of this study is to describe the development of private housing in the city of Padang and identify factors that influence the development of private housing in the city of Padang. The research approach used is deductive qualitative rationality, which in the analysis phase uses a Geographic Information System (GIS) to describe the development of private housing in Padang City in 2007-2016.The results showed that there was a change in the orientation of private housing development from 2007-2016 from the western part of Padang Sarai, Lubuk Buaya, Pasie Nan Tigo, Bungo Padang and Parupuk Tabing villages to the eastern part of Balai Gadang Village, Lubuk Minturun Urban Village, Gunung Sarik Urban Village and Kuranji Village with the addition of $156 \mathrm{Ha}$ of private housing area. Factors affecting housing development in Kota Padang are factors of policy, population factor, land limitation factor, and partnership factor.

Keywords: Kota Padang, development of private housing, factors 


\section{PENDAHULUAN}

Perumahan merupakan kebutuhan dasar bagi manusia selain kebutuhan sandang dan papan (Sastra dan Marlina,2006). Dimana perumahan merupakan perwujudan dari tempat tinggal yang memiliki peranan penting dalam melangsungkan kehidupan manusia. Pontoh dan Kurniawan (238:2009) mengatakan bahwa kawasan permukiman merupakan kawasan yang luasannya paling dominan di kota mencapai $50-60 \%$. Oleh karena itu perkembangan perumahan memiliki peranan penting dalam pembentukan struktur ruang perkotaan.

Pengertian perumahan menurut UndangUndang Republik Indonesia Nomor 1 Tahun 2011 tentang perumahan dan kawasan permukiman adalah kumpulan rumah sebagai bagian dari permukiman, baik perkotaan maupun perdesaan yang dilengkapi dengan prasarana, sarana dan utilitas umum sebagai hasil upaya pemenuhan rumah layak huni. Perumahan swasta yang dimaksud dalam penelitian ini adalah perumahan yang dibangun oleh pengembang (developer) perumahan.

Kota Padang merupakan salah satu Kota Pantai yang terletak di pesisir Barat Pulau Sumatera. Letak wilayah yang strategis menjadikan Kota Padang sebagai tempat tujuan bermigrasi atau pertemuan penduduk bagi wilayah disekitar pesisir barat Pulau Sumatera. Hal tersebut menjadikan Kota Padang semakin cepat berkembang dalam hal perluasan kawasan permukiman disepanjang pelabuhan dan pesisir pantai Kota Padang.

Kota Padang terdiri dari 11 Kecamatan yang dikategorikan menjadi dua yaitu kecamatan pesisir dan kecamatan non pesisir. Lokus wilayah penelitian adalah Kecamatan Koto Tangah dan Kecamatan Kuranji dengan pertimbangan yaitu (1) berdasarkan letak wilayah kedua kecamatan tersebut memiliki perbedaan yaitu Kecamatan Koto Tangah termasuk ke dalam katagori kecamatan pesisir dan Kecamatan Kuranji termasuk ke dalam katagori kecamatan non pesisir, (2) perkembangan perumahan swasta dominan berada di kedua kecamatan tersebut dengan total perumahan 318 perumahan atau sekitar 52,5\% perkembangan perumahan berada di Kecamatan Koto Tangah dan Kecamatan Kuranji, (3) berdasarkan kajian awal menggunakan citra satelit dalam kurun waktu 10 tahun terakhir yaitu tahun 2007-2016 menunjukkan adanya fenomena kecendrungan perubahan orientasi perkembangan perumahan swasta dari wilayah bagian Barat mengarah ke wilayah bagian Timur dengan penambahan luas perumahan mencapai $156 \mathrm{Ha}$.

Perkembangan perumahan swasta akan ditinjau dari tiga titik waktu yaitu tahun 2007, 2012 dan 2016 dengan pertimbangan Tahun 2007 sebagai tahun pengamatan awal perkembangan perumahan swasta sebelum terjadi bencana gempabumi tahun 2009, Tahun 2012 sebagai tahun pengamatan kedua setelah terjadi peristiwa bencana gempabumi tahun 2009 dan menjadi titik balik tata ruang Kota Padang dengan ditandai dengan Revisi RTRW Kota Padang, dan Tahun 2016 sebagai tahun pengamatan ketiga dimana Kota Padang telah menjalankan RTRW dengan melakukan berbagai pembangunan salah satunya pemindahan Pusat Pemerintahan Kota Padang ke Kelurahan Aia Pacah di Kecamatan Koto Tangah.

Fenomena kecendrungan pergeseran perkembangan perumahan swasta ke wilayah pinggiran kota berdampak pada alih fungsi lahan secara besar-besaran dari gunalahan pertanian menjadi gunalahan perumahan dan permukiman sedangkan Kota Padang memiliki keterbatasan lahan pengembangan yaitu kepadatan di wilayah bagian Barat (pusat kota) sudah sangat tinggi, lahan sudah sangat terbatas dan di wilayah bagian Timur (pinggiran kota) berbatasan langsung dengan Kawasan Penyangga dan Lindung sehingga sangat berisiko jika pengembangan perumahan tidak dikendalikan dengan baik. Hal ini menjadi "dilema" bagi Kota Padang karena disatu sisi membutuhkan ruang untuk melakukan pengembangan kota tetapi disisi lain memiliki keterbatasan fisik untuk melakukan pengembangan kota. Oleh karena itu penting untuk mengetahui perkembangan perumahan swasta di Kota Padang dan faktor-faktor apa saja yang mempengaruhi perkembangan perumahan swasta tersebut.

\section{METODE PENELITIAN}

Pendekatan penelitian yang dipergunakan dalam pelitian ini ialah deduktif kualitatif rasionalistik. Sudaryono (2016) menyebutkan bahwa pendekatan deduktif adalah jenis pendekatan dimana teori menjadi acuan bagi peneliti melihat sesuatu hal kemudian teori tersebut diverifikasi ke lapangan dan pengalaman yang terdahulu dijadikan acuan untuk melihat sesuatu ke depan sehingga dapat di artikan peneliti menggunakan fikiran untuk melihat sesuatu yang baru. Menurut Moleong (2000) metode penelitian kualitatif merupakan prosedur penelitian yang merupakan data deskriptif berupa kata-kata tertulis dari orang dan prilaku yang di amati. Untuk menguji kebenaran dalam 
penelitian ini dilakukan dengan cara menggali data-data dari berbagai pihak baik data primer dan data sekunder.

Pengumpulan data dilakukan dengan metode survey primer dan survey sekunder, metode survey primer melakukan pengamatan langsung kondisi perkembangan perumahan swasta dan sebaran pelayanan umum di wilayah penelitian, melakukan wawancara kepada pemerintah, developer dan masyarakat serta melakukan dokumentasi di lapangan sedangkan metode survey sekunder melakukan pengumpulan data dari instansi terkait jumlah sebaran perumahan dan mengumpulkan dokumentasi peta citra tahun amatan 2007,2012,2016.

Unit amatan dalam penelitian ini adalah perubahan luas perumahan swasta, arah pembangunan perumahan swasta, pola perkembangan perumahan swasta dan nilai tanah. Unit analisis berupa perkembangan perumahan swasta di Kecamatan Koto Tangah dan Kecamatan Kuranji.

Data yang digunakan dalam penelitian ini adalah sebaran dan luas perumahan swasta tahun 2007,2012 dan 2016, data fisik, data sebaran pelayanan umum dan data kependudukan guna untuk menggambarkan perkembangan perumahan swasta di wilayah penelitian. Selain itu data yang digunakan berdasarkan observasi lapangan dan wawancara untuk mengkonfimasi perkembangan perumahan swasta dan faktorfaktor yang mempengaruhi perkembangan tersebut.

Adapun variabel yang digunakan dalam penelitian ini untuk menjelaskan perkembangan perkembangan perumahan swasta di Kota Padang adalah (a) p luas perumahan swasta tahun 2007, 2012, dan 2016, (b) arah sebaran perumahan swasta tahun 2007, 2012, dan 2016, (c) pola sebaran perumahan swasta tahun 2007,2012 dan 2016, (d) nilai tanah yang terbentuk tahun 2007,2012 dan 2016. Untuk menjelaskan faktorfaktor yang mempengaruhi perkembangan perumahan swasta di Kota Padang didasarkan pada data sekunder, wawancara, dan pengamatan di lapangan. Adapun variabel yang digunakan adalah (1) faktor kebijakan yang terdiri dari arahan pengembangan perumahan,rencanarencana pembangunan sarana prasarana oleh pemerintah dan terkait mitigasi bencana, (2) faktor penduduk yaitu mengetahui penambahan penduduk dalam kurun waktu 2007-2016 sehingga dapat dikaitkan dengan perkembangan perumahan, (3) faktor keterbatasan lahan di pusat kota yang menyebabkan perkembangan perumahan semakin meluas, (4) faktor kemanan terkait mitigasi bencana yang mempengaruhi dalam persepsi dalam pemilihan lokasi perumahan dan (5) faktor kemitraan yaitu terkait hubungan antar stakeholder (pemerintah, swasta dan masyarakat) dalam perkembangan perumahan. Analisis dilakukan dengan deskriptif kualitatiif berdasarkan hasil wawancara terhadap informan yaitu pihak developer yang melakukan pengembangan perumahan di kawasan penelitian, pihak pemerintahan Kota Padang yaitu Dinas Tata Ruang Tata Bangunan dan Perumahan, dan pihak masyarakat yang bertempat tinggal di perumahan swasta. Hasil wawancara kemudian dilakukan cross check di lapangan dan data sekunder (berupa peta, uraian, dan angka) kemudian diuji dengan teori yang telah menjadi landasan penelitian sehingga dapat ditarik kesimpulan akhir faktor-faktor apa saja yang mempengaruhi perkembangan perumahan di Kota Padang.

\section{HASIL DAN PEMBAHASAN}

Pengolahan dan analisa data menggunakan teknik serial reconstruction map menggunakan GIS (geographic information system) yaitu rekonstruksi peta berdasarkan hasil observasi, wawancara dan data sekunder pada tinjauan waktu 2006,2012 dan 2016 yang kemudian dari hasil analisis tersebut dijelaskan secara kualitatif deskriptif perkembangan perumahan swasta dan faktor-faktor yang mempengaruhi perkembangan tersebut serta melakukan validasi dengan membandingkan hasil wawancara dan pengamatan di lapangan.

Untuk mempermudah analisis maka penulis melakukan penyederhanaan data dengan membagi wilayah penelitian menjadi tiga bagian yaitu wilayah bagian barat, tengah, dan timur

- Pembagian wilayah Kecamatan Koto Tangah: wilayah bagian barat yang terdiri dari Kelurahan Padang Sarai, Kelurahan Lubuk Buaya, Kelurahan Pasie Nan tigo, Kelurahan Bungo Pasang, Kelurahan Batang Kabung Ganting dan Kelurahan Parupuk Tabing. Wilayah bagian tengah terdiri dari Kelurahan Batipuh Panjang, Kelurahan Koto Pulai, Kelurahan Koto Panjang Ikua Koto,Kelurahan Aia Pacah, Kelurahan Dadok Tunggul Hitam dan wilayah bagian timur terdiri dari Kelurahan Balai Gadang dan Kelurahan Lubuk Minturun.

- Pembagian wilayah Kecamatan Kuranji : hanya terdiri dari wilayah bagian tengah dan timur. Wilayah bagian tengah terdiri dari Kelurahan Ampang, Kelurahan Anduring, Kelurahan Ambacang, Kelurahan Lubuk Lintah, Kelurahan Kalumbuk, dan Kelurahan Sei Sapih. Wilayah bagian Timur terdiri dari Kelurahan 
Gunung Sarik, Kelurahan Kuranji, Kelurahan Korong Gadang.

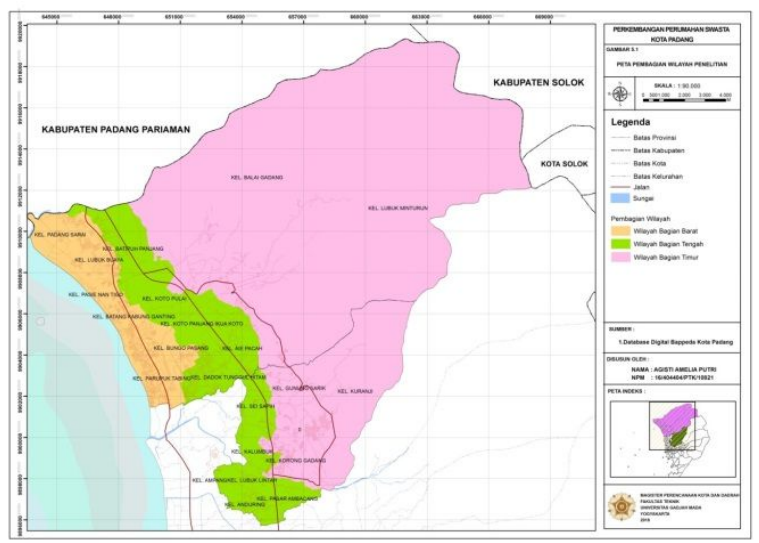

Gambar.1 Pembagian Wilayah Penelitian Sumber: Analisis Penulis,2018

\section{Perkembangan Perumahan Swasta Kota Padang Tahun 2007-2016}

\section{a) Luas Perumahan Swasta Tahun 2007-2016}

Penambahan luas perumahan swasta diperoleh dari hasil overlay peta sebaran perumahan swasta tahun 2007, 2012 dan 2016.

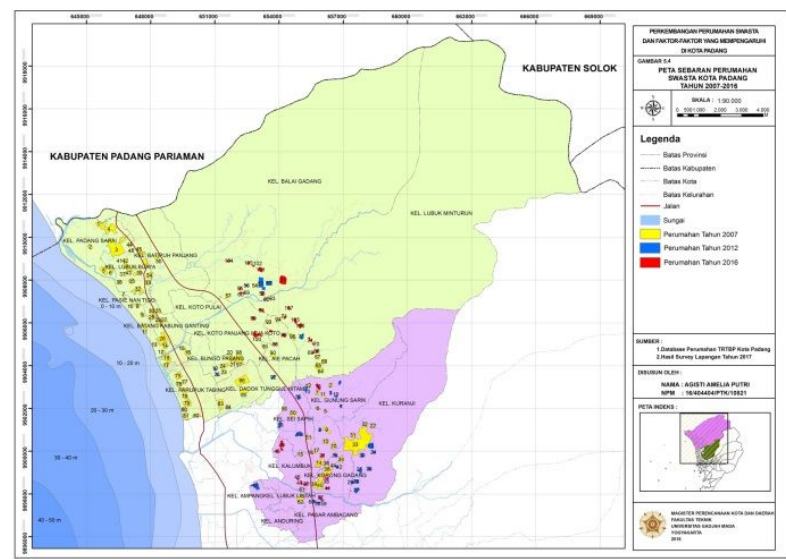

Gambar.2 Peta Sebaran Perumahan Swasta di Wilayah Penelitian Tahun 2006-2017

Sumber: Analisis Penulis,2018

Berdasarkan gambar.1 dan gambar.2 menunjukkan bahwa bahwa luas perumahan swasta terbesar di Kecamatan Koto Tangah tahun 2007-2016 berada di Kelurahan Padang Sarai dengan luas perumahan swasta sebesar $90 \mathrm{Ha}$ memiliki 6 perumahan dan Kelurahan Lubuk Buaya dengan luas sebesar 68 Ha memiliki 18 perumahan. Luas perumahan swasta terbesar di Kecamatan Kuranji dilihat pada tahun 2007-2016 berada di Kelurahan Kuranji dengan luas perumahan swasta sebesar $95 \mathrm{Ha}$ memiliki 4 perumahan dan Kelurahan Gunung Sarik dengan luas perumahan swasta sebesar $47 \mathrm{Ha}$ memiliki 13 perumahan.

\section{b) Arah Sebaran Perumahan Swasta Tahun 2007-2016}

Analisis perkembangan perumahan swasta berdasarkan arah sebaran perumahan swasta akan difokuskan pada arah pembangunan perumahan secara horizontal, vertikal dan interstisial. Zahnd (1999) menjelaskan teori perkembangan wilayah secara umum dapat dilihat dari sisi teknis yaitu perkembangan horizontal merupakan pembangunan mengarah ke arah luar (area pinggir kota) dengan kuantitas dan ketinggian lahan terbangun tetap, perkembangan vertikal merupakan pembangunan mengarah ke atas dengan kuantitas dan daerah terbangun tetap sama tetapi ketinggian bangunan bertambah (area pusat kota), dan perkembangan interstisial merupakan pembangunan ke arah dalam dengan ketinggian rata-rata tetap sama sedangkan kuantitas lahan terbangun bertambah (pemadatan bangunan).

Berdasarkan hasil identifikasi dan observasi dilapangan diketahui bahwa $100 \%$ arah pembangunan perumahan swasta di Kecamatan Koto Tangah dan Kecamatan Kuranji tahun 2006-2017 adalah horizontal.

a) Kecamatan Koto Tangah

- Tahun 2007, sebaran perumahan swasta mengarah ke wilayah bagian barat sebesar 288 Ha dengan jumlah perumahan 55 berkembang secara horizontal.

- Tahun 2012, menunjukkan adanya perubahan arah orientasi perkembangan perumahan swasta dari wilayah bagian barat menuju ke wilayah bagian timur. Hal ini dibuktikan dengan penambahan luas perumahan swasta pada tahun 2007 menuju tahun 2012 sebesar $22 \mathrm{Ha}$ yang tersebar di Kelurahan Balai Gadang sebesar 17 Ha dan Kelurahan Lubuk Minturun sebesar $3 \mathrm{Ha}$ berkembang secara horizontal.

- Tahun 2016, arah sebaran perumahan swasta semakin mengarah ke wilayah bagian Timur yaitu dibuktikan dengan penambahan luas perumahan swasta tahun 2012 menuju tahun 2016 sebesar 39,5 $\mathrm{Ha}$ yang tersebar di Kelurahan Balai Gadang sebesar 23 Ha dan Kelurahan Lubuk Minturun sebesar 16,5 Ha. berkembang secara horizontal.

b) Kecamatan Kuranji

- Tahun 2007, sebaran perumahan swasta mengarah ke wilayah bagian timur yaitu sebesar $142 \mathrm{Ha}$ dengan jumlah perumahan 24 dan berkembang secara horizontal.

- Tahun 2012, sebaran perumahan swasta mengarah ke wilayah bagian Timur yaitu 
sebesar 34 Ha dengan jumlah perumahan yaitu 40 perumahan yang tersebar di Kelurahan Kuranji sebesar $22 \mathrm{Ha}$ dengan jumlah perumahan, Kelurahan Gunung Sarik sebesar 9 Ha dan Kelurahan Korong Gadang sebesar 3 Ha berkembang secara horizontal.

- Tahun 2016, menunjukkan adanya perubahan arah orientasi perkembangan perumahan swasta di Kecamatan Kuranji yaitu dari wilayah bagian Timur bergerak mengarah wilayah bagian tengah yaitu Kelurahan Kalumbuk dengan luas sebesar $9 \mathrm{Ha}$ dan Pasar Ambacang dengan luas 2 Ha. berkembang secara horizontal.

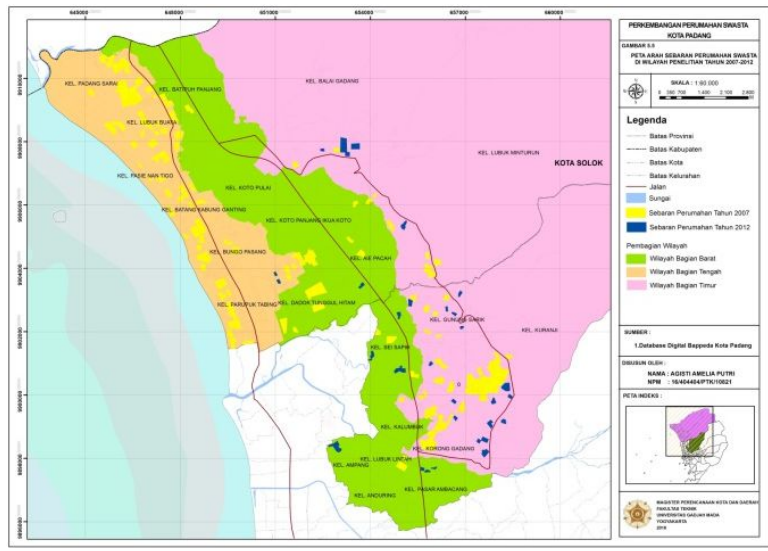

Gambar.3 Peta Arah Sebaran Pembangunan Horizontal di Wilayah Penelitian Tahun 2007-2012 Sumber: Analisis Penulis,2018

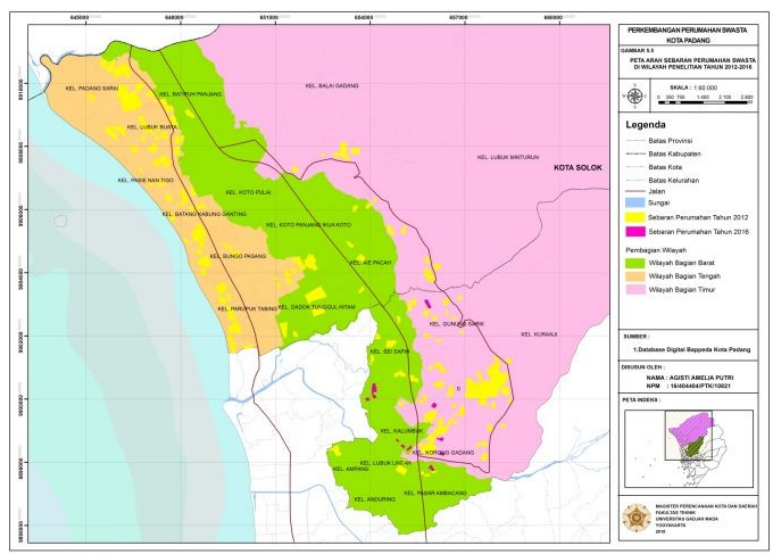

Gambar.4 Peta Arah Sebaran Pembangunan Horizontal di Wilayah Penelitian Tahun 2012-2016 Sumber: Analisis Penulis,2018

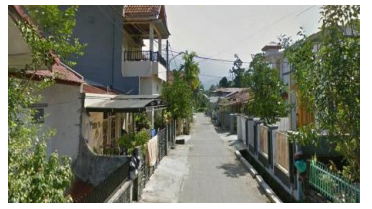

Perumahan Kuranji di Kelurahan Kuranji

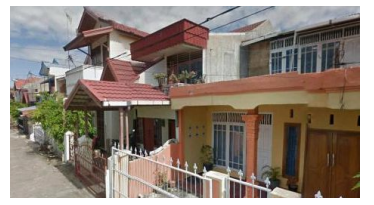

Perumahan Singgalang Di Kelurahan Batang Kabung Ganting
Gambar.5 Kondisi Perumahan Swasta di Wilayah Penelitian berkembang secara horizontal Sumber: Survey Lapangan,2018

\section{c) Pola Sebaran Perumahan Swasta Tahun 2007-2016}

Identifikasi pola sebaran perumahan swasta mengacu pada proses perluasan perkotaan yang diungkapkan oleh Yunus (2008) bahwa terdapat 3 proses perluasan areal kekotaan yaitu perembetan konsentris (consentric development) dicirikan dengan perembetan yang merata ke semua bagian perkotaan yang sudah ada dan jenis perembetan yang sifatnya lambat, perembetan memanjang (ribbon development) dicirikan dengan perembetan kota yang berkembang mengikuti jaringan transportasi yang ada sehingga peran jaringan transportasi memegang peranan yang sangat penting dalam proses perembetan kota jenis ini dan perembetan yang meloncat (leap frog development/checker-board development) dicirikan perembetan kota yang tidak teratur atau meloncat dari kota induk. Tipe perembetan jenis ini merupakan perembetan kota yang tidak efektif dan efisien.

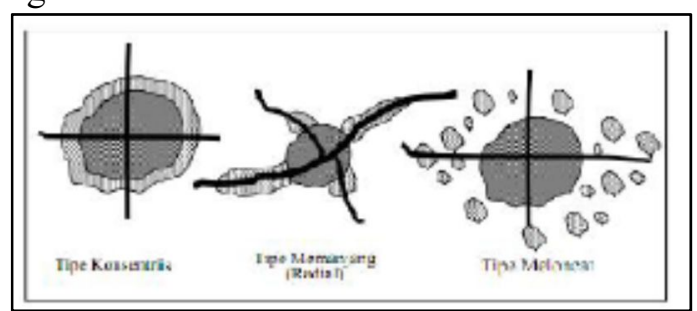

Gambar.4 Pola Perembetan Kenampakan Fisik Kota Ke Arah Luas

Sumber: Yunus (2008)

Identifikasi pola sebaran perumahan swasta

di Kota Padang dilakukan dengan cara interpretasi peta citra satelit wilayah penelitian pada tahun amatan dan kemudian melakukan crosscheck dilapangan sehingga diperoleh pola perkembangan perumahan swasta pada tahun 2007,2012 dan 2016.

Hasil analisis ditemukan bahwa pada (1) tahun 2007 Pola sebaran perumahan swasta yang terbentuk di Kecamatan Koto Tangah terbagi dua yaitu di wilayah bagian Barat (Kelurahan Padang Sarai, Kelurahan Lubuk Buaya, Kelurahan Pasie Nan Tigo, Kelurahan Bungo Pasang, Kelurahan Parupuk Tabing) cenderung berpola memanjang (ribbon development) mengikuti jaringan jalan utama Adinegoro dan didukung kondii topografi yang landai (0-2\%) sehingga memudahkan dalam pengembangan perumahan swasta sedangkan bagian Timur berpola melompat secara acak karena penggunaan lahan didominasi persawahan sehingga pembangunan perumahan mengikuti lahan yang tersedia. Pola sebaran perumahan di Kecamatan Kuranji Terkonstrasi di wilayah bagian Timur (Kelurahan Kuranji, Kelurahan Gunung Sarik, Kelurahan Korong Gadang) 
dengan pola konsentris hal ini dipengaruhi oleh pertemuan jalan By.Pass dan Jalan Lingkar Timur sehingga menjadikan kawasan ini sangat strategis untuk pengembangan perumahan, selain terdapat perumahan paling luas di Kota Padang yaitu Perumahan Belimbing mencapai $88 \mathrm{Ha}$ yang terdapat di Kelurahan Kuranji dan kemudian diikuti dengan sebaran fasilitas umum yang memadai seperti sekolah, kesehatan, pasar dan pertokoan.

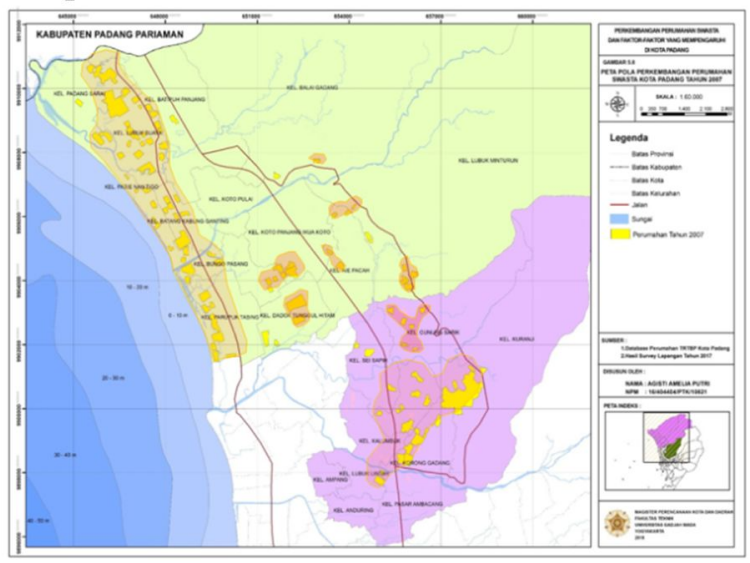

Gambar.5 Peta Pola Sebaran Perumahan Swasta di Kecamatan Koto Tangah dan Kecamatan Kuranji Tahun 2007

(2) Pada tahun 2012 pola sebaran perumahan swasta yang terbentuk di Kecamatan Koto Tangah masih sama dengan pola yang terbentuk pada tahun 2007 yaitu memanjang di wilayah bagian Barat dan melompat secara acak di wilayah bagian Timur begitu pula dengan pola sebaran perumahan swasta di Kecamatan Kuranji masih sama berpola konsentris meliputi Kelurahan Kuranji, Kelurahan Gunung Sarik dan Kelurahan Korong Gadang. Temuan menarik pada pola sebaran perumahan tahun 2012 adalah jika dilihat secara keseluruhan wilayah penelitian Kecamatan Koto Tangah dan Kecamatan Kuranji pola sebaran perumahan yang terbentuk mendekati pola memanjang mengikuti jaringan jalan Lingkar Timur Kota Padang.

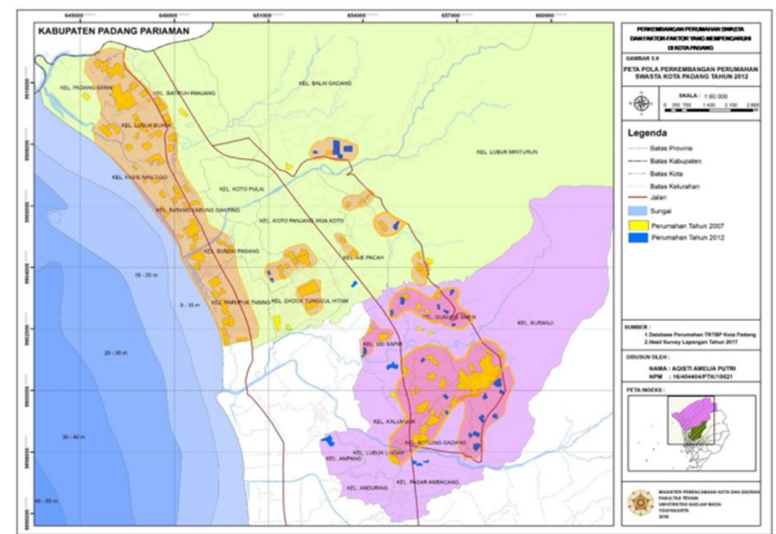

Gambar.6 Peta Pola Sebaran Perumahan Swasta di Kecamatan Koto Tangah dan Kecamatan Kuranji Tahun 2012
(3) Pada tahun 2006 terjadi perubahan pola sebaran perumahan di wilayah bagian Timur Kecamatan Koto Tangah dan Kecamatan Kuranji yaitu yang pada awalnya berpola melompat pada tahun 2016 terlihat berubah membentuk pola memanjang mengikuti Jaringan Jalan Lingkar Timur. Dapat dilihat padan gambar.6 berikut ini.

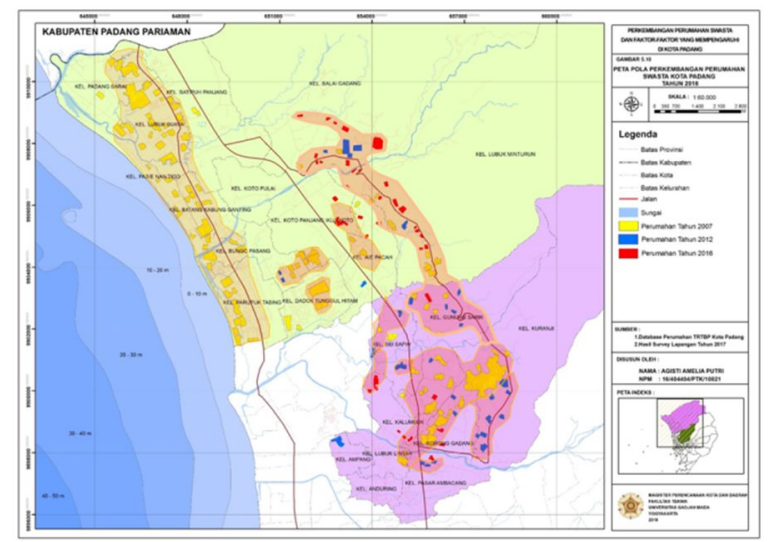

Gambar.7 Peta Pola Sebaran Perumahan Swasta di Kecamatan Koto Tangah dan Kecamatan Kuranji Tahun 2016

\section{d) Nilai Tanah}

Nilai tanah dipengaruhi oleh beberapa hal seperti jarak geografis lokasi tanah dengan pusat kegiatan (Von Thunen, 1826 dalam Rustiadi, dkk,2006), ditentukan oleh derajat aksesibilitas semakin tinggi aksesibilitas suatu lokasi maka semakin tinggi nilainya (Yunus,2008), dan juga perlakukan terhadap tanah tersebut jika terdapat perlakuan positif maka tanah akan bernilai tinggi (Pearch dan Turner,1990). Dalam mekanisme pasar kegiatan-kegiatan yang mempunyai nilai lahan (land rent) lebih tinggi mampu menggeser kegiatan-kegiatan yang mempunyai nilai lahan (land rent) yang lebih rendah, hal ini karena nilai lahan yang lebih tinggi posisi tawarnya (bargaining position) cenderung lebih tinggi. Hal ini menyebabkan timbulnya suatu land rent gradient. Fenomena inilah yang selanjutnya akan mempengaruhi dinamika penggunaan lahan di wilayah perkotaan.

Seperti halnya perkembangan perumahan swasta di Kota Padang yang cenderung mengarah ke wilayah bagian Timur dan diikuti oleh perkembangan fasilitas pelayanan kota dan peningkatan aksesibilitas menuju wilayah pnggiran kota sangat mempengaruhi nilai tanah.

Dalam analisis ini wilayah amatan akan dibagi berdasarkan koridor jaringan jalan dengan radius $1 \mathrm{~km}$ dari wilayah amatan dikarenakan pada jarak tersebut mulai dilakukan pembangunan perumahan. Selain itu kemudahan dan kelancaran aksesibilitas merupakan salah satu faktor penentu nilai lahan. Pembagian 
wilayah amatan terdiri dari tiga koridor jalan yaitu Koridor I Jalan Adinegoro, Koridor II Jalan By Passs dan Koridor III Jalan Lingkar Timur..

Hasil yang ditemukan bahwa dalam 10 tahun terakhir terlihat adanya perubahan nilai tanah di wilayah penelitian. Koridor I yang berada di sekitar kawasan Jalan Adinegoro mengalami peningkatan nilai tanah dari tahun 2007 sampai dengan 2016 mencapai 66,7\%. Untuk Koridor II yang berada di sekitar kawasan Jalan By.Pass mengalami peningkatan nilai lahan mencapai $433,3 \%$. Untuk koridor III yang berada di sekitar Jalan Lingkar Timur mengalami peningkatan nilai lahan mencapai $650 \%$. Perubahan nilai tanah disebabkan oleh adanya perlakuan eksternalitas positif terhadap tanah tersebut seperti dekat dengan jalan utama yaitu Jalan Adinegoro, Jalan By.Pass dan Jalan Lingkar Timur, dekat dengan fasilitas yaitu sarana pendidikan, sarana kesehatan dan dekat dengan sarana perekonomian berupa pasar dan pertokoan.

\section{Faktor-Faktor Perkembangan Perumahan Swasta di Kota Padang}

Faktor-faktor perkembangan perumahan swasta diperoleh dari hasil kajian tinjauan pustaka dari beberapa teori yang relevan terhadap perkembangan perumahan swasta dan kemudian didasarkan pada data sekunder, wawancara, dan pengamatan di lapangan. Analisis dilakukan dengan deskriptif kualitatiif berdasarkan hasil wawancara terhadap informan yaitu pihak developer yang melakukan pengembangan perumahan di kawasan penelitian, pihak pemerintahan Kota Padang yaitu Dinas Tata Ruang Tata Bangunan dan Perumahan, dan pihak masyarakat yang bertempat tinggal di perumahan swasta. Hasil wawancara kemudian dilakukan cross check ke lapangan dan data sekunder (berupa peta, uraian, dan angka) kemudian diuji dengan teori yang telah menjadi landasan penelitian sehingga dapat ditarik kesimpulan akhir faktor-faktor apa saja yang mempengaruhi perkembangan perumahan di Kota Padang.

1) Faktor Kebijakan

Faktor kebijakan mempengaruhi perkembangan perumahan swasta di Kota Padang melalui arahan perkembangan perumahan yang tertuang di dalam rencana pola ruang kawasan budidaya perumahan yang terdapat di rencana tata ruang wilayah Kota Padang serta rencana pembangunan sarana prasarana pelayanan perkotaan oleh pemerintah. Hal tersebut diperkuat dengan hasil wawancara oleh salah staf dinas tata ruang tata bangunan perumahan Kota Padang yang mengatakan bahwa pengembangan perumahan diarahkan di Kecamatan Koto Tangah dan Kecamatan Kuranji dikarenakan pusat kota sudah semakin padat dengan adanya revisi rencana tata ruang wilayah Kota Padang yang mempertimbangkan mitigasi bencana diharapkan adanya pemerataan pembangunan dan pembagian konsentrasi kegiatan yang nantinya dapat meminimalisir dampak jika terjadi bencana. Seperti yang tertuang dalam Standar Nasional Indonesia (SNI) Nomor: 03-1733-2004 tentang persyaratan dasar perencanaan permukiman dan lokasi lingkungan perumahan menyatakan bahwa lokasi perumahan harus sesuai dengan rencana peruntukan lahan yang diatur dalam Rencana Tata Ruang Wilayah dan Kota (RTRW) setempat atau dokumen perencanaan lainnya yang ditetapkan dengan peraturan daerah setempat.

2) Faktor Penduduk

Faktor penduduk mempengaruhi perkembangan perumahan swasta di Kota Padang hal ini dibuktikan dengan hasil analisis yang menunjukkan bahwa penambahan jumlah penduduk disekitar wilayah perencanaan dapat memicu semakin banyaknya perkembangan perumahan swasta disana hal ini dikarenakan wilayah yang semakin ramai dan diikuti semakin lengkapnya fasilitas perkotaan menjadi pemicu berkembangnya perumahan swasta di wilayah tersebut, seperti halnya di Kota Padang. Penambahan jumlah penduduk terbesar di Kecamatan Koto Tangah pada tahun 2007-2012 adalah Kelurahan Balai Gadang dengan penambahan mencapai 11.833 jiwa, pada tahun 2012-2016 penambahan terbesar terdapat di Kelurahan Padang Sarai sebesar 3.297 jiwa. Penambahan jumlah penduduk terbesar di Kecamatan Kuranji dalam kurun waktu 2007-2012 adalah Kelurahan Kuranji mencapai 3.213 jiwa dan pada tahun 20122016 mencapai 3.046 jiwa. Jika dibandingkan penambahan jumlah penduduk dengan penambahan luas perumahan di wilayah penelitian menunjukan persamaan yaitu penambahan luas perumahan terbesar 
berada di Kelurahan Kuranji dan Kelurahan Balai Gadang dan penambahan penduduk juga menunjukkan hal yang sama yaitu penambahan jumlah penduduk terbesar terdapat di Kelurahan Kuranji dan Kelurahan Balai Gadang. Hal tersebut sesuai dengan teori yang diungkapkan oleh Branch (1995) menyatakan bahwa secara fisik perkembangan suatu kota dapat dicirikan dari kependudukan yang semakin bertambah dan makin padat.

3) Faktor Keterbatasan Lahan

Faktor Keterbatasan lahan mempengaruhi perkembangan perumahan swasta melalui identifikasi lahan efektif di wilayah penelitian. Lahan efektif diperoleh dengan cara mengurangi luas wilayah penelitian dengan luas wilayah terbangun, luas lahan lindung (hutan lindung, Kawasan penyangga, sempadan sungai, sempadan pantai, Kawasan khusus) dan sawah berdasarkan pada peta rencana pola ruang Kota Padang. Hasil yang diperoleh menunjukkan bahwa lahan efektif paling sedikit di Kecamatan Kuranji berada di wilayah bagian Barat yaitu Kelurahan Koto Pulai 70,53 Ha dikarenakan sebagain besar kawasan adalah sawah produktif dan Kelurahan Batang Kabung Ganting 139, 17 Ha, Kelurahan Parupuk Tabing $153 \mathrm{Ha}$ dikarenakan telah dipadati oleh lahan terbangun. Dengan keterbatasan lahan diwilayah bagian Barat mejadikan arah pengembangan perumahan bergerak mencari lahan yang masih tersedia seperti di wilayah bagian Timur yaitu Kelurahan Balai Gadang dengan luas lahan efeanaktif sebesar 1.078,26 Ha. Keterbatasan lahan lahan di pusat kota inilah yang mendorong terjadinya alih fungsi lahan menjadikan perluasan areal perkotaan ke arah pinggiran.

4) Faktor Keamanan

Faktor keamanaan dalam perkembangan perumahan swasta terkait dengan kerentanan Kota Padang terhadap bencana. Seperti salah satu teori hirarki kebutuhan yang diungkapkan oleh (Maslow, 1954) bahwa terdapat safety or security needs (kebutuhan akan keamanan) yaitu tempat berlindung bagi penghuni dari gangguan manusia dan lingkungan yang tidak diinginkan.
Berdasarkan hasil wawancara dan tinjauan dilapangan terlihat bahwa setelah peristiwa bencana gempabumi dan isu gelombang tsunami faktor keamanan menjadi pertimbangan bagi masyarakat untuk mencari tempat tinggal khususnya bagi masyarakat yang tinggal di wilayah bagian Barat Kecamatan Koto Tangah atau yang berdekaan dengan pesisir pantai. Masyarakat cenderung memilih wilayah yang lebih tinggi dan jauh dari pesisir pantai agar terhindar dari bahaya tsunami sehingga memperoleh rasa aman dan nyaman. Kota Padang yang merupakan kota dengan kerentanan bencana cukup tinggi menjadikan faktor keamanan sebagai salah satu faktor penentu dalam perkembangan perumahan swasta di Kota Padang.

5) Faktor Kemitraan

Pengembangan perumahan tidak terlepas dari pengaruh tiga stakeholder yaitu pemerintah, swasta dan masyarakat. Penyelenggaraan pembangunan perumahan dalam Undang-Undang Nomor 1 Tahun 2011 tentang perumahan dan kawasan permukiman berasaskan pada kemitraan. Asas kemitraan ini memberikan landasan agar penyelenggaraan perumahan dan kawasan permukiman dilakukan oleh pemerintah dan pemerintah daerah dengan melibatkan peran pelaku usaha dan masyarakat, dengan prinsip saling memerlukan, memercayai, memperkuat, dan menguntungkan yang dilakukan, baik langsung maupun tidak langsung.

Berdasarkan hasil wawancara dengan pihak pemerintah diketahui bahwa untuk memenuhi kebutuhan perumahan pemerintah kota melakukan kebijakan pengaturan ruang untuk pengembangan perumahan di Kota Padang dengan pertimbangan keterbatasan lahan di pusat kota dan terkait mitigasi bencana serta melakukan peningkatan pelayanan kota untuk menunjang kehidupan masyarakat secara merata. Pihak developer sebagai pengembang perumahan harus mengikuti kebijakan yang telah ditetapkan oleh pemerintah, dan developer cenderung memilih lokasi yang telah tersedia sarana 
prasarana atau mendekati lokasi yang memiliki sarana prasarana penunjang guna memudahkan didalam pemasaran penjualan perumahan. Pihak masyarakat diketahui membutuhkan tempat tinggal yang terjangkau, memiliki fasilitas lengkap dan aman terhadap bahaya bencana. Hal tersebut akan tercapai dengan upaya kerjasama pemerintah, swasta dan masyarakat. Pemerintah sebagai pembuat kebijakan memberikan pelayanan terbaiknya dengan melakukan pemerataan pembangunan sarana dan prasarana untuk menunjang perkembangan perumahan di Kecamatan Koto Tangah dan Kecamatan Kuranji, developer sebagai pengembang perumahan mengikuti kebijakan arahan pembangunan perumahan yang mengarah ke Kecamatan Koto Tangah dan Kecamatan Kuranji karena tanah di wilayah tersebut telah memiliki nilai tambah dan potensial untuk pembangunan perumahan serta memiliki sarana prasarana penunjang untuk menarik minat pembeli sedangkan masyarakat yang membutuhkan rumah untuk tempat tinggal tetapi tidak mampu membeli rumah di dekat pusat kota karena harga yang tinggi serta menginginkan lokasi rumah yang aman dari bencana dan memiliki sarana pelayanan umum yang memadai mendapatkan pilihan untuk memiliki rumah. Sehingga dapat disimpulkan bahwa faktor kemitraan antara pihak pemerintah, swasta dan masyarakat mempengaruhi perkembangan perumahan di Kota Padang.

\section{SIMPULAN}

Perkembangan perumahan swasta di Kota Padang terjadi secara bertahap. Berdasarkan hasil analisis dan pengamatan tiga titik tinjauan waktu yaitu 2007, 2012 dan 2016 perkembangan perumahan swasta di Kota Padang memperlihatkan adanya fenomena perubahan orientasi perkembangan perumahan. Perubahan orientasi perumahan yang terjadi adalah perkembangan perumahan swasta yang awalnya berada di wilayah bagian Barat (Kelurahan Padang Sarai, Kelurahan Lubuk Buaya, Kelurahan Pasie Nan Tigo, Kelurahan Bungo Pasang dan Kelurahan Parupuk Tabing mengarah ke wilayah bagian Timur yaitu Kelurahan Balai Gadang, Kelurahan Lubuk Minturun, Kelurahan Gunung Sarik dan Kelurahan Kuranji dengan penambahan luas perumahan swasta sebesar 156 Ha.

Proses perubahan tersebut dapat ditinjau dari empat hal yaitu penambahan luas perumahan swasta, arah pembangunan perumahan swasta, pola sebaran perumahan swasta dan nilai tanah sebagai berikut:

- penambahan luas perumahan swasta menggambarkan adanya perubahan orientasi perkembangan perumahan dari wilayah bagian Barat (wilayah kota) menuju wilayah bagian Timur (wilayah pinggiran), hal tersebut dipengaruhi oleh faktor kebijakan, faktor penduduk, faktor keterbatasan lahan, faktor keamanan dan faktor kemitraan.

- Arah sebaran perumahan swasta memperlihatkan bahwa perkembangan perumahan swasta di Kota Padang secara horizontal. Hal ini dipengaruhi oleh faktor keterbatasan lahan, faktor keamanan dan faktor kemitraan

- Pola perkembangan perumahan swasta di Kota Padang memperlihatkan pola konsentris (consentric development), pola memanjang (ribbon development) dan pola meloncat (leap frog development). hal tersebut dipengaruhi oleh faktor kebijakan, faktor penduduk, faktor keterbatasan lahan dan faktor keamanan.

- Nilai tanah memperlihatkan bahwa dalam 10 tahun terakhir nilai tanah selalu mengalami peningkatan, hal tersebut dipengaruhi oleh faktor kebijakan, faktor penduduk, faktor keterbatasan lahan, faktor keamanan dan faktor kemitraan.

Berdasarkan perkembangan perumahan swasta di Kota Padang dapat dilihat bahwa arah pengembangan perumahan swasta semakin mengarah ke wilayah bagian Timur yang merupakan kawasan pinggiran kota dimana wilayah bagian Timur Kota Padang memiliki keterbatasan fisik yaitu berbatasan langsung dengan Kawasan Penyangga dan Kawasan lindung. Apabila perkembangan perumahan swasta tidak terkendali dengan baik dikhawatirkan akan dapat mengancam kelestarian lingkungan. Perkembangan perumahan swasta yang berkembang ke arah pinggiran kota yaitu wilayah bagian Timur akan menjadi salah satu penyebab fenomena urban sprawl di Kota Padang yaitu fenomena terjadinya pemekaran kota yang secara acak, tidak terstruktur tanpa diawali dengan sebuah rencana. Salah satu bentuk nyata dari proses urban sprawl di 
kawasan pinggiran adalah meningkatnya jumlah pembangunan perumahan secara horizontal yang tersebar di kawasan pinggiran kota. (Setioko,2009 dalam Hanief dan Dewi,2014).

Berdasarkan urain kesimpulan diatas maka terdapat rekomendasi dari penelitian ini yang ditunjukkan kepada pemerintah, developer sebagai pengembang perumahan dan masyarakat. Rekomendasi pertama adalah kepada pemerintah Kota Padang perlu adanya kebijakan lebih detail terkait perkembangan perumahan swasta hal ini disebabkan karena Kota Padang memiliki keterbatasan fisik pengembangan kota yatu wilayah bagin Barat yang berbatasan dengan Samudera Hindia dan sebelah Timur berbatasan dengan Bukit Barisan sedangkan diketahui bahwa kebutuhan perumahan terus meningkat. Selain itu dengan mengetahui kecenderungan perkembangan perumahan swasta di Kota Padang tahun 2007-2016 hendanya dapat menjadi menjadi panduan dan rekomendasi bagi pihak pemerintah, swasta (developer) maupun masyarakat dimasa yang akan datang dalam penentuan atau pemilihan lokasi perumahan dengan mempertimbangkan faktor kebencanaan. Diharapkan pembangunan perumahan tidak hanya mengedepankan keuntungan semata tetapi lebih mengedepankan keberlanjutan sehingga tercapai masa depan yang lebih baik.

Rekomendasi juga diberikan kepada para peneliti selanjutnya yang ingin meneliti terkait perkembangan perumahan swasta di Kota Padang. Penelitian perkembangan perumahan swasta dan faktor-faktor yang mempengaruhi di Kota Padang diharapkan mampu menjadi masukkan bagi peneliti sebelumnya.Peneltian ini masih memiliki banyak kekurangan. Penelitian ini secara umum membahas perkembangan perumahan swasta di Kota Padang untuk kedepannya diharapkan peneliti lain dapat meneliti seperti strategi- strategi apa saja yang diperlukan dalam menghadapi perkembangan perumahan swasta di masa yang akan dagatitang sehingga dapat meminimalisir dampak negatif dan menciptakan pembangunan yang berkelanjutan.

\section{DAFTAR PUSTAKA}

Branch.M.C. 1995. Perencanaan Kota Komprehensif: pengantar \& penjelasan. Gadjah Mada University Press, Yogyakarta.

Daljoeni, N. 1998. Geografi Kota dan Desa. Alumni, Bandung
Daljoeni, N. 1997. Geografi Baru-Organisasi Keruangan Dalam Teori dan Praktik. Alumni, Bandung.

Moleong, L. J. 1998. Metodelogi Penelitian Kualitatif, Edisi IV. Rake Sarasin, Bandung.

Pontoh.N.K dan Kustiawan Iwan. 2008. Pengantar Perencanaan Perkotaan. Penerbit ITB, Bandung.

Sastra Suparno, Marlina Endi. 2005. Perencanaan dan Pengembangan Perumahan. Andi, Yogyakarta.

Yunus.H.S 2008. Dinamika Wilayah Peri-Urban Determinan Masa Depan Kota. Pustaka Pelajar, Yogyakarta.

Pemerintah R.I. 2004. "SNI Nomor 03-1733-2004

Tata cara perencanaan lingkungan perumahan di perkotaan"

Pemerintah R.I. 2007. "Undang - Undang Nomor 26 Tahun 2007 tentang Penataan Ruang”. Jakarta.

Pemerintah R,I. 2011. "Undang - Undang Nomor 1 Tahun 2011 tentang Perumahan dan Kawasan Permukiman”, Jakarta.

Pemerintah Kota Padang. 2012. "Rencana Tata Ruang Wilayah Kota Padang Tahun 20102030" 